\title{
Correction: Ubiquitylation of MFHAS1 by the ubiquitin ligase praja2 promotes M1 macrophage polarization by activating JNK and p38 pathways
}

Jing Zhong ${ }^{1,2}$, Huihui Wang ${ }^{3}$, Wankun Chen ${ }^{1,2}$, Zhirong Sun ${ }^{1,2}$, Jiawei Chen ${ }^{1,2}$, Yajun Xu ${ }^{1,2}$, Meilin Weng ${ }^{1,2}$, Qiqing Shi', Duan $\mathrm{Ma}^{5}$ and Changhong Miao ${ }^{1,2,3}$

Correction to: Cell Death \& Disease; https://doi.org/ 10.1038/cddis.2017.102; published online 4 May 2017.
The PDF and HTML versions of the article have been updated to include the Creative Commons Attribution 4.0 International License information.

Published online: 16 July 2018

\footnotetext{
Correspondence: Duan Ma (duanma@fudan.edu.cn) or

Changhong Miao (miaochh@aliyun.com)

${ }^{1}$ Department of Anesthesiology, Fudan University Shanghai Cancer Center, Shanghai, China

${ }^{2}$ Department of Oncology, Shanghai Medical College, Fudan University,

Shanghai, China

${ }^{3}$ Jiangsu Province Key Laboratory of Anesthesiology, Xuzhou Medical College,

Xuzhou, China

${ }^{4}$ Department of Anesthesiology, Children's Hospital of Fudan University,

Shanghai, China

${ }^{5}$ Key Laboratory of Metabolism and Molecular Medicine, Ministry of Education, Department of Biochemistry and Molecular Biology, Collaborative Innovation Center of Genetics and Development, Institute of Biomedical Sciences, School

of Basic Medical Sciences, Fudan University, Shanghai, China
}

\section{(c) The Author(s) 2018}

(c) (i) Open Access This article is licensed under a Creative Commons Attribution 4.0 International License, which permits use, sharing, adaptation, distribution and reproduction By in any medium or format, as long as you give appropriate credit to the original author(s) and the source, provide a link to the Creative Commons license, and indicate if changes were made. The images or other third party material in this article are included in the article's Creative Commons license, unless indicated otherwise in a credit line to the material. If material is not included in the article's Creative Commons license and your intended use is not permitted by statutory regulation or exceeds the permitted use, you will need to obtain permission directly from the copyright holder. To view a copy of this license, visit http://creativecommons.org/licenses/by/4.0/. 